\title{
Correction to: Dynamics of Total Microcystin LR Concentration in Three Subtropical Hydroelectric Generation Reservoirs in Uruguay, South America
}

\author{
Mauricio González-Piana ${ }^{1} \cdot$ Daniel Fabián $^{1} \cdot$ Andrea Piccardo $^{1} \cdot$ Guillermo Chalar $^{1}$
}

Published online: 24 October 2017

(C) Springer Science+Business Media, LLC 2017

\section{Correction to: Bull Environ Contam Toxicol}

(2017) 99:488-492

DOI 10.1007/s00128-017-2158-7

The original version of this article contains mistakes. The author inadvertently mentioned units $\mathrm{mg} / \mathrm{L}$ in all the places of first paragraph under "Results and discussion" section. The correct unit is $\mu \mathrm{g} / \mathrm{L}$. In second paragraph, 10th line under "Results and discussion" section, the value should read as $\left(<0.05-85.4 \mu \mathrm{g} / \mathrm{mm}^{3}\right)$ instead of $(<0.05-854.00 \mu \mathrm{g} /$ $\left.\mathrm{mm}^{3}\right)$. The units and value are corrected through this erratum.

The online version of the original article can be found under doi:10.1007/s00128-017-2158-7.

Mauricio González-Piana

magopi2009@gmail.com

Daniel Fabián

danielfabianroland@gmail.com

Andrea Piccardo

andreapiccardo12@gmail.com

Guillermo Chalar

gchalar@fcien.edu.uy

1 Limnology Section, Faculty of Sciences, Institute of Ecology and Environmental Sciences, University of the Republic, Montevideo, Uruguay 